\title{
Amniocentesis Results According to Risk Factors: A Result of 1026 Women With Advanced Maternal Age
}

\author{
Risk Faktörlerine Göre Amniyosentez Sonuçları: Ileri Anne Yașı Olan 1026 Kadının Sonucu
}

\author{
Tuncay Yüce ${ }^{1}$, Erkan Kalafat ${ }^{1}$, Batuhan Özmen ${ }^{1}$, Acar Koç ${ }^{1}$, Feride Söylemez
}

Ankara Üniversitesi Tıp Fakültesi Kadın Hastalıkları ve Doğum AD.

Corresponding Author

Tuncay Yüce, M.D.

Phone: +90.312 .5958506$

Fax: +90 3123203553

E-mail: drtuncayyuce@gmail.com

Ankara University School of Medicine, Cebeci Hospital,

Department of Obstetrics and Gynecology Ankara Turkey

Aim: To compare amniocentesis results of women above age of 35 according to their risk factors (maternal age alone vs maternal age and biochemical risk

Method: This was a retrospective cohort study including a population of pregnant women who underwent amniocentesis between years 2006 and 2014. Women were grouped into two according to their risk factor (age alone vs age and biochemical risk). Abnormal amniocentesis results were compared among groups.

Results: 702 women with only maternal age risk and 324 women with combined age and biochemical risk were included in study (1026 in total). Mean age of the study population was $38,11 \pm 2,66$. Biochemical risk group had 27 fetuses $(8,3 \%)$ with Trisomy 21 while advanced age only risk group had 18 fetuses $(2,5 \%)$ diagnosed with Trisomy 21. When added to age factor, biochemical factors increased detection of Trisomy 21 significantly (Odds ratio : 3,56 $\mathrm{p}<0,001$ ).

Conclusion: Advanced maternal age alone can be used to detect a small percentage of chromosomal abnormality cases, and its use as an indication for invasive procedures should be at clinician's discretion along with patient consent. Biochemical factors added to maternal age risk increases detection rates and combined risk offers a more solid indication for invasive procedures

Key Words: Amniocentesis, Advanced Maternal Age, Biochemical Factors

Amaç: 35 yaș ve üzerindeki gebelerde risk faktörlerine göre amniyosentez sonuçlarının karșılaștırılması (ileri anne yașı ve ileri anne yașı ile birlikte olan biyokimyasal risk)

Metod: Retrospektif çalıșmamız 2006 ile 2014 yılları arasında yapılan amniyosentez vakalarını içermektedir. Risk faktörlerine göre (anne yașı ve anne yașı ile birlikte olan biyokimyasal risk) iki gruba ayrılmıștır.

Bulgular: Sadece anne yașı nedeniyle 702 gebe, anne yașı ile birlikte biyokimyasal riski olan 324 gebe çalıșmaya alınmıștır (toplam 1026 gebe). Çalıșma grubunda ortalama yaș 38,11 $\pm 2,66$ dır. Biyokimayasal risk grubunda 27 fetus (\%8,3), sadece yass riski olan grupta 18 fetusda $(\% 2,5)$ trizomi 21 saptanmıstır. Biyokimyasal risk mevcut olan grupta yaș riski olan gruba göre trizomi riski anlamlı olarak daha yüksektir (Odds ratio: 3,56 $\mathrm{p}<0,001$ ).

Sonuç: Sadece anne yașı riski olan gebelerde kromozomal anomali tespit etme oranı düșüktür. Bu hasta grubunda invaziv isslem için klinisyen ve hasta birlikte karar vermelidir. Anne yașı ile birlikte biyokimyasal risk gebelerde invaziv ișlem yapmak ve kromozomal anomaliyi tespit etmek için daha güçlü bir göstergedir.

Anahtar Sözcükler: Amniyosentez, Ileri Anne Yașı, Biyokimyasal Risk

Incidence of major chromosomal anomalies (structural and numeric) in Turkey is reported to be between 3\% - 4.9\% with Trisomy 21 being the most commonly diagnosed anomaly during midtrimester. Prenatal diagnosis of chromosomal anomalies is usually done with invasive procedures, most commonly amniocentesis. Incidence of major chromosomal abnormalities diagnosed with invasive diagnostic procedures are around 0,9-6,7\%. To increase detection rates and prevent unnecessary procedures, maternal age, biochemical factors and ultrasonographic markers have been suggested as risk factors. Calculation of risk factors for selective use of invasive procedures led to increased detection rates (1-3).

Maternal age of 35 is the cut-off value used in most screening tests. However majority of women with anomalous infants are below 35 years old and by using advanced maternal age as an indication for diagnostic work-up; we are only able to diagnose a mere $30-50 \%$ of all chromosomal abnormalities. Adding ultrasonographic markers to maternal age for risk calculation increases 
detection rates, however only $57 \%$ of the patients with down syndrome have abnormal findings at midtrimester ultrasonography scan (4).

Biochemical tests improve detection rate by 5,5 fold compared to maternal age alone as risk determinant (5). Combined testing with age and biochemical markers for risk determination is usually recommended. Although biochemical and ultrasonographic markers aided physicians in selective use of invasive procedures with improved detection rates, maternal age alone is still an indication for invasive procedures in common practice setting (5).

However some of the available research does not support usage of invasive procedures due to advanced maternal age alone. Controversy over the subject is present up to day and some researchers advocate raising the 35 years old age threshold while others claim ultrasonographic and biochemical markers alone are sufficient to determine patients under risk.

In our research we investigated results of amniocentesis procedures performed on women over age 35. Impact of biochemical factors and ultrasonographic markers on diagnosis rate was our primary outcome measure.

\section{Method}

We retrospectively analysed results of amniocentesis procedures done between years 2006 and 2014 in Ankara University Hospital. Results of women over 35 years old with singleton pregnancies were included for analysis. Women under 35 years old, multiple pregnancies were excluded from analysis. Amniocentesis procedures were performed due to one of the following indications; pathological ultrasonography findings, increased aneuploidy risk revealed by biochemical testing, history of anomalous infant or increased aneuploidy risk due to maternal age. First trimester aneuploidy screening consisted of free-BHCG and PAPPA while second trimester aneuploidy screening consisted of free-BHCG, inhibin A, oestriol and AFP. 1:270 was the cut-off for increased risk. Abnormal ultrasonographic findings were heart anomalies, diaphragmatic hernia, duodenal atresia, abdominal wall defects, fetal effusion/hydrops, hydrocephalus, mild ventriculomegaly, and thickened nuchal fold $(>6 \mathrm{~mm})$.

SPSS 21.0 for Windows was used for data analysis. For comparison of frequency values chi square test was used. Variables with a normal distribution were compared using $\mathrm{t}$ test Mann Whitney. U test was used for variables that did not have a normal distribution. A $p$ value $<0.05$ was statistical cut-off for significance.

\section{Results}

Between years 2006 and 2014, 2436 amniocentesis procedures were performed. We included women over age of 35 with singleton pregnancies in our study for analysis $(n=1026)$. All of the sample population were singleton pregnancies and belonged to same ethnicity. 39 women in the study sample had diabetes mellitus. 25 women with diabetes had normal risk according to biochemical testing, and remaining 14 had increased risk according to biochemical testing. Risk ratio difference between groups was not statistically significant $(\mathrm{p}=0,863)$

Mean age of the study population was $38,11 \pm 2,66$. Most of the study

Table 1: Trisomy 21 results distribution according to maternal age.

\begin{tabular}{|c|c|c|c|c|c|c|c|c|c|c|c|c|c|c|}
\hline Age & & 35 & 36 & 37 & 38 & 39 & 40 & 41 & 42 & 43 & 44 & 45 & 46 & 49 \\
\hline Total Amniocentesis & & 189 & 151 & 187 & 158 & 117 & 98 & 59 & 20 & 12 & 19 & 7 & 5 & 4 \\
\hline & $47,+21$ & 5 & 5 & 7 & 8 & 3 & 2 & 2 & 2 & 1 & 3 & 2 & 3 & 2 \\
\hline Abnormal Result & $47,+13$ & 0 & 0 & 1 & 0 & 0 & 0 & 1 & 1 & 0 & 0 & 0 & 0 & 0 \\
\hline & $45, \times 0$ & 0 & 0 & 0 & 0 & 1 & 0 & 0 & 1 & 0 & 0 & 0 & 0 & 0 \\
\hline & $47, X X Y$ & 0 & 0 & 1 & 0 & 0 & 0 & 1 & 0 & 0 & 0 & 0 & 0 & 0 \\
\hline
\end{tabular}

population were multigravid women with a mean gravidy of $2,73 \pm 1,28$. Maternal age was the sole risk factor for testing in majority of the study population $\quad(n=633, \quad 61,6 \%)$. Advanced maternal age along with biochemical factors indicating high risk were observed in 324 parturients making up $31,5 \%$ of the study population. Ultrasonographic findings in addition to advanced maternal age were observed in 65 parturients (6,3\%). History of anomalous baby comprised a small portion of the study population (n:3, $0,29 \%)$

Amniocentesis results revealed 52 fetuses with chromosomal abnormalities. Majority of the abnormal results were Trisomy 21 ( $n=45,4,38 \%)$, followed by Trisomy 13 (n:3, 0,29\%). Turner syndrome (n:2 0,19\%) and Klienfelter syndrome (n:2 0,19\%) consisted remainder of test results. Number of patients diagnosed with Trisomy 21 according to their ages are shown in Table 1.

65 women in the study sample had pathological ultrasonographic findings. 3 fetuses $(4,6 \%)$ in this group had trisomy 21, 3 fetuses $(4,6 \%)$ had trisomy 13 . When we break down the remainder of the study group who did not have pathological ultrasonography findings, we found out 42 fetuses $(4,3 \%)$ had trisomy 21, 2 fetuses $(0,2 \%)$ had monosomy $\mathrm{X}$ and 2 fetuses $(0,2 \%)$ had Klienfelter Syndrome. Prevalence of trisomy 21 between 2 groups did not differ significantly ( $p$ value: 0,732 ). 
324 pregnant women in the study sample had increased risk related to biochemical factors. Amniocentesis results of this group revealed 27 fetuses $(8,3 \%)$ with trisomy 21 while amniocentesis results of women with advanced age as only risk factor diagnosed 18 fetuses $(2,5 \%)$ with trisomy 21. Statistical analysis of these findings shown that biochemical factors added to advanced age risk increases detection of trisomy 21 significantly (OR: 3,56, 95\% CI: 1,92-6,56, p value: $<0,001)$ (Table 2). Mean age of two groups were $38,2 \pm 2,47$ for biochemical risk group and 37,79 $\pm 2,50$ for advanced age only group ( $p$ value: 0,003 ).

\section{Discussion}

Rate of amniocentesis procedures performed with advanced age only risk indication varies between 18,4\% and $67,1(6,7)$. In Turkey rate of $29 \%$ to $52,9 \%$ has been reported $(3,8)$ and in our study sample $42,1 \%$ of the study population consisted of women with advanced age only as risk factor.

A total number of 1026 amniocentesis results were evaluated in our study and $5 \%$ of all amniocentesis results were abnormal. Literature data shows a varying abnormal result rate of $0,9 \%$ to $6,7 \%$ according to study sample. And of all the prenatally diagnosed Trisomy 21 cases, 60\% of them had elevated risk due to biochemical factors. In our study $31,5 \%$ of all study group had elevated biochemical risk while $55,7 \%$ of the patients with abnormal amniocentesis results had elevated risk due to biochemical factors. A similar study by Quing-wei Q iet al (5). reported biochemical factors increase detection rate of trisomy 215,54 fold compared to advanced maternal age alone $(5,6,9)$.

A recent study from Kohatsu et al (10). 2012 reported $82,3 \%$ of anomalous fetuses had either an abnormality detachable by ultrasound or increased nuchal translucency. In our study only 11,5 of the study population had abnormal ultrasonographic findings and ultrasonography alone did not increase trisomy detection rate significantly (OR: 1,1 95\% CI: 0,96$1,92$ p value: 0,739$)$.

Table 2: Amniocentesis results according to risk factors

\begin{tabular}{|l|c|c|c|c|}
\cline { 2 - 3 } \multicolumn{1}{c|}{} & \multicolumn{2}{c|}{ Amniocentesis results } & \multirow{2}{*}{ p value } & Total \\
\cline { 2 - 3 } \multicolumn{1}{c|}{} & Trisomy 21 & Normal Karyotype & & \\
\hline Advanced Maternal Age Alone & $18(2.5 \%)$ & $684(97,5)$ & & 702 \\
\hline $\begin{array}{l}\text { Advanced Maternal Age + } \\
\text { Biochemical Factors }\end{array}$ & $27(8,3 \%)$ & $297(91.7 \%)$ & $<0,01$ & 324 \\
\hline Count & $45(4.3 \%)$ & $981(95.7 \%)$ & & 1026 \\
\hline
\end{tabular}

Cumulative data suggests advanced maternal age alone should not be an indication for invasive procedures $(11,12)$. However contradicting reports also exist; while admitting advanced maternal age alone as an indication for amniocentesis substantially increases number of interventions, there is a small, albeit significant percentage of trisomy cases detachable through maternal age risk (13).

In our retrospective analysis, we have seen biochemical factors increase detection rate of trisomy 21 significantly. Effects of biochemical factors on detection of other chromosomal abnormalities are less pronounced. Ultrasonography alone did not increase detection rates of trisomy 21. However, in conjunction with biochemical factors and advanced maternal age it increases detection rates.

In summary, advanced maternal age alone can be used to detect a small percentage of chromosomal abnormality cases, and its use as an indication for invasive procedures should be at clinicians discretion along with patient consent. Biochemical factors added to maternal age risk increases detection rates and combined risk offers a more solid indication for invasive procedures.

Declaration of interest: The authors report no conflicts of interest. 


\section{REFERENCES}

1. Goddijn M, Joosten JH, Knegt AC, et al. Clinical relevance of diagnosing structural chromosome abnormalities in couples with repeated miscarriage. Hum Reprod. 2004;19:1013-1017.

2. Balkan M, Akbas H, Kalkanli S, et al. Evaluation of clinical and cytogenetic findings on 1,068 second-trimester amniocenteses in Southeast Turkey. Clin Exp Obstet Gynecol. 2011;38:364-368.

3. Karaoğuz MY, Bal F, Yakut T, et al. Cytogenetic results of amniocentesis materials: incidence of abnormal karyotypes in the Turkish collaborative study. Genet Couns. 2006;17:219-230.

4. Bottalico JN, Chen X, Tartaglia M, et al. Second-trimester genetic sonogram for detection of fetal chromosomal abnormalities in a community-based antenatal testing unit.Ultrasound Obstet Gynecol. 2009;33:161-168

5. Qi QW, Jiang YL, Zhou XY, et al. Genetic counseling, prenatal screening and diagnosis of Down syndrome in the second trimester in women of advanced maternal age: a prospective study. Chin Med J. 2013;126(11):2007-2010.

6. Han SH, An JW, Jeong GY et al. Clinical and cytogenetic findings on 31,615 midtrimester amniocenteses. Korean J Lab Med. 2008; 28: 378-385.

7. Chang YH, Chen PY, Li TY, et al. Discrepancy of cytogenetic analysis in Western and Eastern Taiwan. Pediatric Neonatology 2013;54:161-165.

8. Ocak Z, Ozlü T, Yazıcıoglu HF, Ozyurt $\mathrm{O}$, Aygün M. Clinical and cytogenetic results of a large series of amniocentesis cases from Turkey: report of 6124 cases. Journal of Obstetrics and Gynaecology Research 2013;40:139-146.

9. Danisman N, Kahyaoglu S, Celen S, et al. A retrospective analysis of amniocenteses performed for advanced maternal age and various other indications in Turkish women. Journal of Maternal-Fetal Neonatal Medicine 2013; 26:242-245.
10. Kohatsu M, Carvalho MH, Vieira Francisco RP, Amorim Filho AG, Zugaib M. Analysis of fetal and maternal results from fetal genetic invasive procedures: an exploratory study at a University Hospital. Revista da Associacao Medica Brasileira 2012;58:703-708.

11. Berkowitz RL, Roberts J, Minkoff $\mathrm{H}$. Challenging the strategy of maternal agebased prenatal genetic counseling. Journal of the American Medical Association 2006;295:1446-1448.

12. ACOG Practice Bulletin No. 77: Screening for fetal chromosomal abnormalities. Obstet Gynecol 2007;109: 217- 227.

13. Bornstein E, Lenchner E, Donnenfeld A, et al. Advanced maternal age as a sole indication for genetic amniocentesis; risk benefit analysis based on a large database reflecting the current common practice. Journal of Perinatal Medicine 2009; 37:99-102. 